\title{
WORKLOAD, REPETITIVE WRIST MOVEMENTS, YEARS OF SERVICE WITH CARPAL TUNNEL SYNDROME
}

\author{
Ratna Kurnia Sari ${ }^{a}$, Diki Bima Prasetio ${ }^{b^{*}}$, Ratih Sari Wardani ${ }^{\mathrm{c}}$ \\ a,b,c Faculty of Public Health ; Universitas Muhammadiyah Semarang ; \\ 18 Kedungmundu Raya Street; Semarang 50273 ; Indonesia
}

\begin{abstract}
Carpal Tunnel Syndrome (CTS) is an occupational disease caused by disruption of the hand position which is constantly and is often associated with activities that use the hands for a long time can affect nerves, blood supply to the hands and wrists. This study aims to determine the relationship between workload, repetitive wrist movements and work time with carpal tunnel syndrome in cantel eyelash workers. Type of research is observational with cross-sectional approach. The sample in study were 50 eyelash workers who were part of the cantel. The results of this study are there is no relationship between workload and the incidence of CTS $(p=1.000)$, there is a relationship between repetitive wrist movements with the incidence of CTS $(p=0.031)$ and There is a relationship between years of service and the incidence of CTS $(p=0.007)$. The conclusion is repetitive wrist movements performed by workers during years of work are a risk factor for carpal tunnel syndrome. So that to reduce this risk, it is necessary to stretch your hands before working, every two hours of work and finish working.
\end{abstract}

Keywords: CTS; repetitive wrist movements; years of service

\section{Introduction}

Carpal Tunnel Syndrome (CTS) can hinder the production process due to pain which can reduce productivity for workers in the informal sector (Kusuma S.P., 2012). The incidence of CTS in the UK reaches 6-17\% while in America it is $5 \%$ (Jenifer, et al., 2016). Research on hairdressers in Turkey was $74.3 \%$ CTS (Demiryurek B.E. \& Gündoğdu A.A., 2018), on tea leaf picking workers in Malang, Indonesia $65.9 \%$ CTS (Bahrudin M., et al., 2016), on sequin workers in Jepara, Indonesia 28.2\% CTS (Ayu D., 2017).

The incidence of CTS is caused by factors of workload, repetitive wrist movements and length of work. Workload is a condition in which workers are faced with tasks that must be completed at a certain time according to their type of work (Sumakmur, 2013), (Tarwaka, 2014). Static muscle loading for a long enough time will result in RSI (Repetition Strain Injuries), namely muscle, bone, tendon pain and decreased blood

*) Corresponding Author (Diki Bima Prasetio)

E-mail: dikibimaprasetio@unimus.ac.id flow, so that lactic acid accumulates and results in muscle fatigue caused by repetitive or repetitive types of work (Ratna, 2016).

Repetitive wrist movements are performed every few seconds, which can result in fatigue and muscle tension in the tendons (Barry, 2018). Research on stone-breaking workers in Konawe Selatan, Indonesia found a relationship between repetitive wrist movements and the incidence of CTS (Sekarsari D., et al., 2017). The period of work indicates that the longer the exposure in the workplace, the higher the risk of developing CTS. Workers who pick chili stalks with a working life of more than 7 years have a risk 17 times higher than workers who pick chilies with a working period of less than 7 years (Kintan et al, 2012), (Wulandari N.N., 2016).

The workers who make the cantel eyelashes use their right hand to attach them while their left hand is used to tighten their hair. This work causes the oxygen supply to the muscles to decrease so that the metabolic process is inhibited. As a result there is an accumulation of 
lactic acid which causes pain in the muscles (Sekarsari D., et al., 2017).

Based on the results of interviews in a preliminary study of 10 workers who manufacture cantel eyelashes. As many as 70\% of workers feel tingling and pain in the hands. Meanwhile, $30 \%$ of workers do not feel tingling and pain in the hand that performs repetitive movements of the wrist as much as \pm 30 movements per minute.

This study aims to determine the relationship between workload, repetitive wrist movements and work time with carpal tunnel syndrome in cantel eyelash workers.

\section{Method}

Type of research is observational with cross-sectional approach. This study conducted observations and measurements of the variables at one particular point in time (Tualeka A.R., 2019). The sample in this study were 50 eyelash workers who were part of the cantel. Study in Rakit Village, Rakit District, Banjarnegara Regency, Central Java Province, Indonesia. The study was conducted in July-August 2018. Independent variables in the study included workload, repetitive wrist movements, years of service. The dependent variable was carpal tunnel syndrome.

This research has received ethical clearance permission from the Health Research Ethics Commission of the Faculty of Public Health, Universitas Muhammadiyah Semarang (043/KEPK-FKM/UNIMUS/2018). Primary data sources were obtained after respondents agreed to become respondents by signing informed consent. The primary data sources consist of pulse measurement results for workload and counting the number of repetitive movements for repetitive movements of the wrist with a stopwatch. conducted interviews for tenure and Phalen test measurements for carpal tunnel syndrome. Data analysis used the Pearson Chi-Square test.

\section{Result and Discussion}

The work of the cantel lashes is done by hooking the stranded hair using the cantel tool. After lined up, the hair is pulled so that it is tight and neatly styled by hand. The tools used are hooks, strings or threads, coat boards, rulers, and hair. The method of installation is to prepare all the materials, take the hair and attach it to the strings or threads that are already stretched on the coated board then pull and trim according to the length of the hair that is attached using a ruler (Figure 1).

The home industry for making eyelashes, which is located at RW 01 Rakit Village, has been around for a long time, where most of the workers are housewives. It can take 15-20 minutes to work on a single lash, from putting the strings on to tightening and straightening lashes. Eyelashes can be done at home within 5 days. Usually, workers can make 10-20 lashes which are then selected by "sensir" (foreman) before being deposited in the factory.

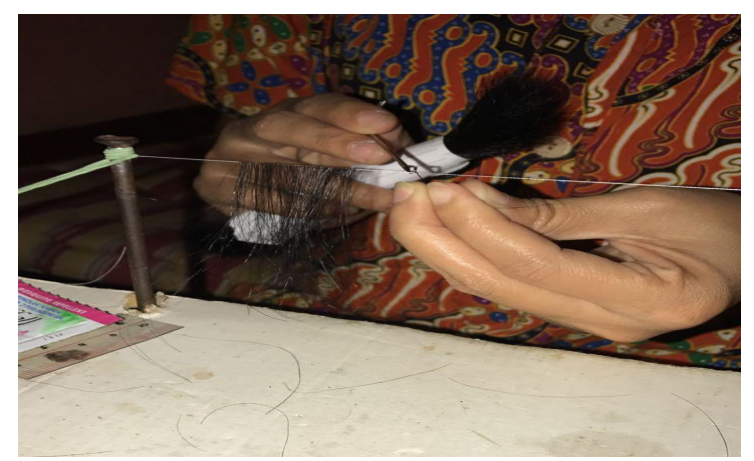

Figure 1. Cantel Eyelash Work

Table 1. Univariate Analysis

\begin{tabular}{|c|c|c|}
\hline Variables & $\mathrm{f}$ & $\%$ \\
\hline \multicolumn{3}{|l|}{ Age } \\
\hline$\geq 30$ years & 20 & 40 \\
\hline$<30$ years & 30 & 60 \\
\hline \multicolumn{3}{|l|}{ Length of Working } \\
\hline$\geq 8$ hours/day & 39 & 78 \\
\hline$<8$ hours/day & 11 & 22 \\
\hline \multicolumn{3}{|l|}{ Body Mass Index (BMI) } \\
\hline Heavy Grease $\left(\geq 27.0 \mathrm{Kg} / \mathrm{m}^{2}\right)$ & 1 & 2 \\
\hline Light Grease (25.1-27.0 Kg/m²) & 2 & 4 \\
\hline Normal $\left(18.5-25.0 \mathrm{Kg} / \mathrm{m}^{2}\right)$ & 31 & 62 \\
\hline Lightweight (17.0-18.4 Kg/m²) & 10 & 20 \\
\hline Skinny Weight $\left(<17.0 \mathrm{Kg} / \mathrm{m}^{2}\right)$ & 6 & 12 \\
\hline \multicolumn{3}{|l|}{ Streaching } \\
\hline Yes & 19 & 38 \\
\hline No & 31 & 62 \\
\hline \multicolumn{3}{|l|}{ Carpal Tunnel Syndrome } \\
\hline Positive & 22 & 44 \\
\hline Negative & 28 & 56 \\
\hline \multicolumn{3}{|l|}{ Workload } \\
\hline Weight $(\geq 126-150$ beats/minute) & 2 & 4 \\
\hline Moderate (101-125 beats/minute) & 6 & 12 \\
\hline Mild (< 100 beats/minute) & 42 & 84 \\
\hline \multicolumn{3}{|l|}{ Repetitive Wrist Movements } \\
\hline At Risk ( $\geq 30$ movements/minute) & 34 & 68 \\
\hline Not at Risk (<30 movements/minute) & 16 & 32 \\
\hline
\end{tabular}




\begin{tabular}{lcc}
\hline Variables & $\mathrm{f}$ & $\%$ \\
\hline Years of Service & & \\
At Risk $(\geq 4$ years $)$ & 18 & 36 \\
Not at Risk $(<4$ years) & 32 & 64 \\
\hline
\end{tabular}

Most workers have an age $<30$ years $(60 \%)$, a work period of $\geq 8$ hours/day (39\%), a bodymass index of $18.5-25.0 \mathrm{Kg} / \mathrm{m}^{2}(62 \%)$, do not do any stretching $(62 \%)$. Workers who have negative carpal tunnel syndrome (56\%), light workload < 100 beats/minute, Doing Repetitive Wrist Movement $\geq 30$ movements/minute $(68 \%)$, and who have a service life $<4$ years $(64 \%)$.

Table 2. Bivariate Analysis

\begin{tabular}{|c|c|c|c|c|c|c|c|}
\hline \multirow{3}{*}{ Variables } & \multicolumn{4}{|c|}{ Carpal Tunnel Syndrome } & \multirow{3}{*}{$p$} & \multirow{3}{*}{$\mathrm{RP}$} & \multirow{3}{*}{$\mathrm{CI}$} \\
\hline & \multicolumn{2}{|c|}{ Positive } & \multicolumn{2}{|c|}{ Negative } & & & \\
\hline & $\mathrm{f}$ & $\%$ & f & $\%$ & & & \\
\hline \multicolumn{8}{|l|}{ Workload } \\
\hline$\geq 126-150$ beats $/$ minute & 1 & 50 & 1 & 50 & \multirow{2}{*}{1.000} & \multirow{2}{*}{1.143} & \multirow{2}{*}{$0.273-4.740$} \\
\hline$<125$ beats/minute & 21 & 43.8 & 27 & 56.2 & & & \\
\hline \multicolumn{8}{|l|}{ Repetitive Wrist Movements } \\
\hline$\geq 30$ movements/minute & 19 & 55.9 & 15 & 44.1 & \multirow{3}{*}{0.031} & \multirow{3}{*}{2.980} & \multirow{3}{*}{$1.030-8.627$} \\
\hline$<30$ movements/minute & 3 & 18.8 & 13 & 81.3 & & & \\
\hline \multicolumn{5}{|l|}{ Years of Service } & & & \\
\hline$\geq 4$ years & 13 & 72.2 & 5 & 27.8 & \multirow{2}{*}{0.007} & \multirow{2}{*}{2.568} & \multirow{2}{*}{$1.376-4.791$} \\
\hline$<4$ years & 9 & 28.1 & 23 & 71.9 & & & \\
\hline
\end{tabular}

There is no relationship between workload and the incidence of CTS $(p=1.000)$. Although this study has no relationship, the results of the CTS positive weight category workload $(50 \%)$ tend to be high. The workload with a heavy category $\geq 126-150$ beats/minute occurs due to static muscle loading for a long time will result in RSI (Repetition Strain Injuries), namely muscle, bone, tendon pain and decreased blood flow, so that lactic acid accumulates and results in fatigue muscles caused by repetitive or repetitive types of work that can lead to CTS events (Ratna, 2016).

The findings in this study that the incidence of CTS was mostly experienced by light-moderate workloads because the respondent's age was $<30$ years old, thus protecting the incidence of CTS. Meanwhile, the heavy category workload that experienced CTS was experienced by respondents with a work period of $\geq 4$ years, working time of $\geq 8$ hours/day and repetitive wrist movements of $\geq 30$ movements/minute.

Repetitive movements are a series of movements that vary slightly and are performed every few seconds, which can result in fatigue and tendon tension. If the time spent resting does not reduce the effect, or if the movement also involves awkward positions or requires a lot of exertion, the risk of tissue damage and other musculoskeletal problems may increase.
Repetitions with a time of less than 30 seconds have been considered repetitive motion (Dewi et al, 2017).

A person who works by performing repetitive movements of the hand and wrist which is a repetitive work activity that involves movement of the hand or wrist or fingers is a risk factor for CTS which has an influence on the physical workload factor. The higher the frequency of repetitive movements, the higher the risk of CTS (Fadhila, et al., 2020). Stone breaking workers in Sumbersari and Sukowono Districts, Jember Regency. Of the 49 respondents, workers suffering from CTS symptoms performed repetitive movements $>30$ times/minute with a total of 30 people $(90.9 \%)$. The analysis showed a significant relationship between repetitive movements and symptoms of CTS (Lazuardi A.I., 2016).

In a study conducted on women picking jasmine in Karangcengis Village, Purbalingga Regency, it is known from the results of the analysis with the chi-square statistical test that there is a relationship between the frequency of repetitive movements with CTS $(p=0.013)$. This means that a high frequency of repetitive movements $>30$ movements per minute in work will cause CTS to occur. The higher the frequency of repetitive movements the higher the risk of developing CTS (Fadhila, et al., 2020). This study is also in line with 
stone breaking workers in Moramo Utara sub-district, South Konawe Regency in 2016, there is a relationship between repetitive wrist movements and the incidence of CTS $(p=0.020)$ (Sekarsari D., et al., 2017).

The same thing is also shown from the results of previous studies that there is a relationship between repetitive motion and complaints of carpal tunnel syndrome in sewing work at the Convection I section of PT. Dan Liris Sukoharjo with statistical test results of the relationship between repetitive motion and complaints of carpal tunnel syndrome showed a value $(p=0.000)$ (Dewi at al, 2017).

Increasing the repetition of the same movement every day will increase the risk for Carpal Tunnel Syndrome. This damage can cause compression of the nerve and cause CTS. Repetitive motion will increase the pressure on the carpal tunnel. Emphasis on the carpal tunnel will cause either reversible or irreversible damage. The increase in intensity and duration is long enough, will reduce blood flow to the peripheral blood vessels. Over a long period of time blood flow will affect capillary circulation and ultimately have an impact on the permeability of blood vessels in the wrist (Fadhila, et al., 2020).

There is a relationship between repetitive wrist movements with the incidence of CTS $(\mathrm{p}=0.031), \mathrm{RP}=2.980$, where $\mathrm{CI}=1.030-8.627$ so that repetitive wrist movements are a risk factor for CTS. Repetitive wrist movements $\geq 30$ movements/minute cause skeletal muscle complaints because muscle contraction exceeds $20 \%$ due to overwork with long hours of work, so blood circulation to the muscles decreases according to the level of constriction which is influenced by the amount of force required (Wan J., et al., 2017).

There is a relationship between tenure and the incidence of CTS $(p=0.007)$. $\mathrm{RP}=2,568$ where $\mathrm{CI}=1,376-4,791$ so that tenure is a risk factor for CTS. The longer the exposure to repetitive hand movements in the workplace, the higher the risk of developing CTS (Fanny, 2018).

The findings of this study indicate that a work period of $\geq 4$ years is at risk of experiencing CTS, while research in Malang on tea leaf pickers showed that $65.9 \%$ of workers experienced CTS after a period of 30 years of work (Bahrudin M., et al., 2016). Another study on chili stalk picking workers with a working tenure of more than 7 years had a 17 times higher risk compared to workers picking chili stalks with a working life of less than 7 years, OR $=17,000 ; 95 \% \mathrm{CI}$ 1.683-171.70 (Kintan et al, 2019), (Wulandari N.N., 2016). Workers who have a work period of $\geq 4$ years have an 18,096 times greater risk of experiencing CTS than workers whose work periods are 1-4 years (Lazuardi A.I., 2016).

The results of this study are in line with research on computer operators at the Secretariat of the Inspectorate General of the Ministry of Public Works $(p=0.000)$. There is a significant relationship between suspected Carpal Tunnel Syndrome (CTS) and a service period of $\geq 4$ years (Erlangga, 2018). Research on female employees at the Dhyana Pura University Campus who work using computers, respondents who have a work period of $\geq 4$ years $(100 \%)$ positively experience CTS and there is a relationship between work tenure and complaints of CTS $(p=0.001)$ (Juniari G.A.R. \& Triwahyudi A., 2015).

\section{Conclusion and Suggestion}

Repetitive wrist movements and years of work were factors associated with carpal tunnel syndrome, whereas workload was not. So to reduce this risk, it is necessary to stretch the hands before working, every two hours of work and finish working. The limitation of this research is the data collection process, where the information provided by the respondents sometimes does not show the respondent's opinion actually because of the possible differences in thinking. It is necessary to do further research on related variables that are risk factors for carpal tunnel syndrome.

\section{Acknowledgments}

Thanks to the research team, to the cantel eyelash worker in Rakit Village, Rakit District, Banjarnegara Regency, and all parties involved and assisting this research.

\section{References}

Agustin, C. P. M. (2012). Masa Kerja, Sikap Kerja dan Kejadian Sindrom Karpal 
pada Pembatik. KEMAS: Jurnal Kesehatan Masyarakat, $7(2), 170-176$. https://doi.org/10.15294/kemas.v7i2. 2814

Association, A. I. H. (2011). The Occupational Environment: Its Evaluation, Control and Management. Anna D.H (ed.). Virginia: American Industrial Hygiene Association.

Ayu, D. (2017). Faktor Risiko Suspect Carpal Tunnel Syndrome pada Pemasang Payet (Studi di Dukuh Cemani Desa Bategede Kecamatan Nalumsari Jepara). (A2A214011/012/S1FKM/V/2017). Unpublished Undergraduate Thesis. Universitas Muhammadiyah Semarang. Semarang.

Bahrudin, M., Perdana, R. L. P., \& Sultana, H. F. A. (2016). Hubungan Masa Kerja dengan Kejadian CTS pada Pekerja Pemetik Daun Teh. Saintika Medika: Jurnal Ilmu Kesehatan Dan Kedokteran Keluarga, 12(1), $24-29$. https://doi.org/10.22219/sm.v11i2.42 05

Demiryurek, B. E., \& Gündoğdu, A. A. (2018). Prevalence of Carpal Tunnel Syndrome and Its Correlation with Pain amongst Female Hairdressers. International Journal of Occupational Medicine and Environment Health, 31(3), 333 - 339. https://doi.org/https:/ / doi.org/10.13 075/ijomeh.1896.01068

Fitriani, R. N. (2012). Faktor-Faktor yang Berhubungan dengan Dugaan Carpal Tunnel Syndrome (CTS) pada Operator Komputer Bagian Sekretariat di Inspektorat Jenderal Kementerian Pekerjaan Umum Tahun 2012. (108101000016). Unpublished Undergraduate Thesis. Universitas Islam Negeri Syarif Hidayatullah. Jakarta.

Ibrahim, I., Khan, W. S., Goddard, N., \& Smitham, P. (2012). Carpal tunnel syndrome: a review of the literature. The Open Orthopaedics Journal, 6, 6976.

https://doi.org/10.2174/187432500120 6010069

Juniari, G. A. R., \& Triwahyudi, A. (2015). Hubungan antara Masa Kerja terhadap Keluhan Carpal Tunnel Syndrome (CTS) pada Pegawai Perempuan di
Kampus Universitas Dhyana Pura yang Bekerja Menggunakan Komputer. VIRGIN: Jurnal Ilmiah Kesehatan Dan Sains, 1(2), 162-168.

Kurniawan, B., Jayanti, S., \& Setyaningsih, Y. (2008). Faktor Risiko Kejadian Carpal Tunnel Syndrome (CTS) pada Wanita Pemetik Melati di Desa Karangcengis, Purbalingga. Jurnal Promosi Kesehatan Indonesia, $3(1), \quad 31 \quad-\quad 37$. https://doi.org/10.14710/jpki.3.1.31-3 7

Kusuma, S. P. (2009). Higene Perusahaan dan Kesehatan Kerja. Jakarta: Gunung Agung.

Kusuma, S. P. (2012). Higiene Perusahaan dan Kesehatan Kerja. Jakarta: Sagung Seto.

Lazuardi, A. I. (2016). Determinan Gejala Carpal Tunnel Syndrome (CTS) pada Pekerja Pemecah Batu (Studi pada Pekerja Pemecah Batu di Kecamatan Sumbersari dan Sukowono Kabupaten Jember). (112010101067). Unpublished Undergraduate Thesis. Universitas Jember. Jember.

Rina, T. I. M. (2010). Hubungan Repetitive Motion dengan Keluhan Carpal Tunnel Syndrome pada Pekerjaan Menjahit di Bagian Konveksi I PT. Dan Liris Sukoharjo. (R.0206090). Unpublished Undergraduate Thesis. Universitas Sebelas Maret. Surakarta.

Sekarsari, D., Pratiwi, A. D., \& Farzan, A. (2017). Hubungan Lama Kerja, Gerakan Repetitif dan Postur Janggal pada Tangan Dengan Keluhan Carpal Tunnel Syndrome (CTS) pada Pekerja Pemecah Batu di Kecamatan Moramo Utara Kabupaten Konawe Selatan Tahun 2016. Jurnal Ilmiah Mahasiswa Kesehatan Masyarakat, 2(6), 1 - 9. https://doi.org/10.37887/jimkesmas.v 2i6.12245

Tarwaka. (2010). Ergonomi Industri: Dasar-dasar Pengetahuan Ergonomi dan Aplikasi di Tempat Kerja. Harapan Press.

Tualeka, A. R. (2019). Metodologi Penelitian Kesehatan dan Keselamatan Kerja. Surabaya: Airlangga University Press.

Wahyuningrum, A. (2013). Beberapa Faktor yang Berhubungan dengan Kejadian Carpal Tunnel Syndrome (CTS) pada Wanita Pelinting Jenang. (A2A009001). 
Unpublished Undergraduate Thesis. Universitas Muhammadiyah Semarang. Semarang.

Wan, J., Qin, Z., Wang, P., Sun, Y., \& Liu, X. (2017). Muscle Fatigue: General Understanding and Treatment. Experimental \& Molecular Medicine, 49(10), $\quad 1 \quad-\quad 11$. https://doi.org/10.1038/emm.2017.19 4

Wulan, E. D. M. (2010). Pengaruh Beban Kerja terhadap Denyut Nadi Tenaga Kerja di Bagian Mekanik di PT. Indo
Acidatama. Tbk. Kemiri, Kebakkramat, Karanganyar. (R.0206069/3618/2010). Unpublished Undergraduate Thesis. Universitas Sebelas Maret. Surakarta.

Wulandari, N. N. (2016). Hubungan Umur, Masa Kerja, IMT dan Frekuensi Gerakan Repetitif dengan Kejadian Carpal Tunnel Syndrome (Studi Pada Pekerja Pemetik Tangkai Cabai). (A2A214051). Unpublished Undergraduate Thesis. Universitas Muhammadiyah Semarang. Semarang. 